\title{
How Far Is It from Warsaw to Luxembourg and Karlsruhe: The Impact of the PSPP Judgment on Poland
}

\author{
Stanisław Biernat*
}

(Received 02 July 2020; accepted 07 July 2020)

\begin{abstract}
A concern was voiced in commentaries after the PSPP judgment that the BVerfG's position regarding the refusal to apply in Germany the CJEU judgment as issued on an ultra vires basis might be used in EU Member States infringing the rule of law, and the independence of the judiciary in particular. This issue is presented in relation to Poland. The article sets out the constitutional provisions which proclaim openness to European integration, as well as the union-friendly case-law of the Constitutional Tribunal (CT) until 2016. The CT jurisprudence at that time provided, however, for the possibility of refusing to apply EU law in exceptional situations, even though this never happened. Next, the article discusses endeavors of the new Polish authorities since the end of 2015 which drastically breach the rule of law in the field of the judiciary, as well as the measures taken by EU institutions to counteract these adverse phenomena. The Polish authorities argue that the competence to define the legal position of the judiciary has not been conferred on the Union and remains within the exclusive competence of the Member States. Such a stance was also taken by the politically dependent CT in April 2020. The PSPP judgment was therefore welcomed with joy by Polish politicians. There are major differences, however, between the rulings of the BVerfG and those of the Polish CT in its current composition, and the hopes pinned on the PSPP judgment by the Polish authorities are unfounded.
\end{abstract}

\section{A. Introduction}

The judgment of the German Federal Constitutional Court (Bundesverfassungsgericht-BVerfG) of May 5, 2020 in the Public Sector Purchase Program (PSPP) ${ }^{1}$ case will probably be regarded as one of the most important rulings of this court, alongside the judgments on the Maastricht ${ }^{2}$ or Lisbon Treaties. ${ }^{3}$ A huge number of commentaries were written about it during the first weeks after its publication, so far mainly on the Internet, and many interviews have been given in various media. The following will not discuss the content of the PSPP judgment. Instead, the considerations below are inspired by remarks which noted the satisfaction with which the authorities in Poland immediately received the BVerfG judgment in the PSPP case. ${ }^{4}$ This is visually illustrated

${ }^{\star}$ Prof. Dr. Dr. h.c. Stanisław Biernat, Jean-Monnet-Professor of European Law, Jagiellonian University, Krakow, Retired judge of the Constitutional Tribunal of Poland; Vice-president of the Tribunal from 2010 to 2017, stanislaw.biernat@uj.edu.pl.

${ }^{1}$ Bundesverfassungsgericht [BVerfG] [Federal Constitutional Court], Case No. 2 BvR 859/15 (May 5, 2020), http://www. bverfg.de/e/rs20200505_2bvr085915en.html [hereinafter Judgement of May 05, 2020].

${ }^{2}$ Bundesverfassungsgericht [BVerfG] [Federal Constitutional Court] Oct. 12, 1993, 89 EnTSCHEIDUNGEN DES BUNDESVERFASSUNGSGERICHTS [BVERFGE] 155 [hereinafter Maastricht Judgement].

${ }^{3}$ Bundesverfassungsgericht [BVerfG] [Federal Constitutional Court] June 30, 2009, 123 EnTSCHEIDUNGEN DES BundESVERFASSUNGSGERICHTS [BVERFGE] 267.

${ }^{4} \mathrm{M}$. Avbelj, The Right Question about the FCC Ultra Vires Decision, VerfassungsBLOG (May 6, 2020), https://verfassungsblog. de/the-right-question-about-the-fcc-ultra-vires-decision/; R. D. Kelemen, P. Eeckhout, F. Fabbrini, L. Pech, \& R. Uitz, National 
by the title of one blog post: "In Poland the champagne corks are popping." ${ }^{5}$ The German constitutional court was criticized for failing to take into account the wider, negative effects of its judgment, although it was aware of them. The harsh wording of the judgment was taken note of. What is meant here is, e.g. an assessment of the interpretation of the Treaties in the judgment of the Court of Justice of the European Union (CJEU) as "simply not comprehensible and thus objectively arbitrary", not to mention the very assertions of acting "ultra vires." It was pointed out that this phrase could be picked up and used in autocratic countries, especially Poland and Hungary, invoking the authority of a respected constitutional court to challenge obligations under EU law and negating the final character of CJEU judgments. There would be no grounds for denying the courts in other Member States the right to do what the German court was allowed to do.

Shortly after the judgment in the PSPP case, Andreas Voßkuhle gave an interview to the weekly magazine Die Zeit, which included a reference to Poland. ${ }^{6}$ The journalist's truculent statement: "And Poland is almost celebrating that the Federal Constitutional Court has confirmed the primacy of national law over European law", was answered firmly by the BVerfG President: "Poles do what they do, regardless of what we do.... And once again: do we really want to be guided by how Polish or other politicians might possibly react to a decision? Is that to be the benchmark for a constitutional court?" To that, Andreas Voßkuhle added his interpretation of the recent judgment: "Our Judgment just says that the CJEU should control more and more intensively; this does not seem to me to be in line with the position of the Polish government."

The abovementioned statements lead to considering what the significance for Poland may be of the view expressed in the PSPP judgment that some CJEU rulings may not apply in Germany as a Member State, as issued on an ultra vires basis. Of course, the impact can only be indirect ${ }^{7}$. It is worth analyzing this issue taking into account the attitude of the current Polish authorities towards EU institutions in relation to the allegations of violation of the rule of law by Poland.

It is indispensable, however, to start by setting the further considerations in a broader constitutional framework and the jurisprudence of the Polish Constitutional Tribunal (CT). This will show the deeper context of the problem in question, even if it goes unnoticed in the current debate.

\section{B. Constitutional Basis of Poland's Membership in the $\mathrm{EU}^{8}$}

The Constitution of the Republic of Poland ${ }^{9}$ was passed in 1997, seven years before accession to the EU. It does not provide specific rules applicable to the process of European integration or the position of European Union law. Instead, the provisions applicable to international organizations,

Courts Cannot Override CJEU Judgments: A Joint Statement in Defense of the EU Legal Order, VerFASSUNGSBLOG (May 26, 2020), https://verfassungsblog.de/national-courts-cannot-override-cjeu-judgments/; M. Maduro, Some Preliminary Remarks on the PSPP Decision of the German Constitutional Court, VERfassungsBloG (May 6, 2020), https://verfassungsblog.de/somepreliminary-remarks-on-the-pspp-decision-of-the-german-constitutional-court/; F.C. Mayer, Auf dem Weg zum Richterfaustrecht?: Zum PSPP-Urteil des BVerfG, VerfassungSBlog (May 7, 2020), https://verfassungsblog.de/auf-dem-wegzum-richterfaustrecht/; P. Meier-Beck, Ultra vires?, D’KART (May 11, 2020), https://www.d-kart.de/blog/2020/05/11/ultravires/.

${ }^{5}$ Mayer, supra note 4 (translated by the author).

${ }^{6}$ Andreas Voßkuhle, "Erfolg ist eher kalt", ZEIT OnLINE (May 13, 2020) (translated by the author).

${ }^{7}$ An analysis of the case law until 2011 has shown that the BVerfG case law was certainly most frequently referred to even though sometimes "decoratively" in the statements of grounds for judgments of the Polish CT amongst European constitutional courts: In 39 judgments, whilst other constitutional courts (Austrian, Hungarian, and the French Conseil Constitutionnel) 3 times each only, and other courts even less frequently or not at all. More recent analyses have not been performed.

${ }^{8}$ See Stanisław Biernat, Offene Staatlichkeit: Polen, in Handbuch Ius Publicum Europaeum, Band II: Offene StaAtlichkeit-Wissenschaft vom Verfassungsrecht 243 (A. von Bogdandy, P. Cruz Villalón, \& P. M. Huber eds., 2007).

${ }^{9}$ See Const. OF THE RePUb. OF POLAND (English translation), https://www.sejm.gov.pl/prawo/konst/angielski/kon1.htm. The translation of certain provisions of the Constitution into English in this paper is slightly different. 
international agreements, and international law also determine the constitutional position of the EU and EU law.

The starting point is Article 9 of the Constitution proclaiming Poland's favorability to international law: "The Republic of Poland shall respect international law binding upon it." The political basis for Poland's accession to the Union is Article 90 paragraph 1, called the "European Clause", although its potential scope is wider: "The Republic of Poland may on the basis of an international agreement delegate to an international organization or international institution the competences of organs of the state authority in certain matters." In turn, the place of international law and thus EU law is determined by Article 91 of the Constitution:

1. A ratified international agreement, upon its publication in Dziennik Ustaw Rzeczypospolitej Polskiej [Journal of Laws of the Republic of Poland], shall constitute part of the national legal order, and shall be applied directly, unless its application depends on the enactment of a statute.

2. An international agreement that has been ratified upon prior consent granted in a statute shall have precedence over a statute, if the statute in question cannot be reconciled with the agreement.

3. If an agreement, ratified by the Republic of Poland, establishing an international organization so provides, the law established by such organization shall be applied directly, and have precedence in the event of a collision with statutes.

It should be noted that the above provision proclaims the primacy of the EU Treaties (Article 91 paragraph 2) and secondary law (Article 91 paragraph 3) over statutes. However, Article 8 paragraph 1 of the Constitution remains unaffected: "The Constitution shall be the supreme law of the Republic of Poland." International agreements, including EU Treaties, can be both the object and the benchmark of control exercised by the CT (Article 188 points 1-3 of the Constitution).

\section{Relevant Case Law of the Constitutional Tribunal (CT)}

The provisions of the Constitution need to be supplemented in the context discussed here by quoting excerpts from the judgments of the CT which interpret the scope of Poland's binding obligations under EU law. It is noteworthy, however, that two periods can be distinguished in the activity of the Polish CT, which was established in 1985: until $2016^{10}$ and since 2017 until the present. During the first period, the Tribunal was an independent constitutional court enjoying prestige in Poland and abroad. The situation has changed since 2017. The Tribunal has since then been chaired by a person appointed for this position-in the opinion of an overwhelming majority of lawyers - in violation of the Constitution and the statutes. The legitimacy of some of the new judges is being denied in the legal community as they have been elected to the seats already occupied by judges from whom the President refused to take the oath in 2015. The composition of the adjudicating panels for cases of political importance is determined or changed by the new President of the Tribunal in violation of the existing legislation.

The following judgments were issued by the "old" CT. ${ }^{11}$

Most important is the judgment of 2005. ${ }^{12}$ The CT ruled in it that the provisions of the Treaty of Accession and many of the contested provisions of the TEU and TEC are constitutional.

\footnotetext{
${ }^{10}$ In 2016, the Constitutional Tribunal was ignored by the parliament and the government and its rulings were not published which was a manifest violation of the Constitution.

${ }^{11}$ See Selected Rulings of the Polish Constitutional Tribunal Concerning the Law of the European Union (2003-2014) (2014), https://trybunal.gov.pl/uploads/media/SiM_LI_EN_calosc.pdf. The three judgments presented below are available there.

${ }^{12}$ Polish Constitutional Tribunal, Judgement of May 11, 2005, Ref. No. K 18/04.
} 
Moreover, the CT formulated many statements concerning the role of Community (EU) law in the Polish legal order. In the context of these considerations, the interpretation of, inter alia, Article 90 paragraph 1) of the Constitution concerning the delegation of powers of state organs only "in certain matters" deserves attention. This implies a prohibition on the delegation of all competences of state authority or those determining in substantial scope their activities or concerning the entirety of the matters within a certain field. The provision in question does not authorize the delegation of competences to such an extent that it would signify the inability of the Republic of Poland to continue functioning as a sovereign and democratic state. In no event may it lead to results contradicting the explicit wording of constitutional norms or being irreconcilable with the minimum guarantee functions realized by the Constitution. In particular, the norms of the Constitution within the field of individual rights and freedoms indicate a minimum and unsurpassable threshold which may not be lowered or questioned as a result of the introduction of Community provisions.

The Tribunal emphasized that the accession of Poland to the European Union did not undermine the supremacy of the Constitution over the whole legal order. In the event of an inconsistency between a constitutional norm and that of the Community which cannot be eliminated/ reconciled by an interpretation based on relative autonomy of European and national law, the nation as the sovereign, or a body of state authority empowered by the Constitution to represent the nation, would need to take a decision choosing between three options. These are: amending the Constitution; causing modifications within Community provisions; or, ultimately, decide on Poland's withdrawal from the European Union.

Of particular relevance is in this context another statement formulated in the judgment obiter dicta: The Member States maintain the right to assess whether or not, in issuing particular legal provisions, the Community (Union) legislative authorities acted within the conferred competences and in accordance with the principles of subsidiarity and proportionality. Should the adoption of provisions infringe these frameworks, the principle of primacy of Community law fails to apply with respect to such provisions. The cited wording means a reference to the concept of EU institutions acting ultra vires, without using this terminology though. This idea was only mentioned and not developed in the judgment under discussion. It was not upheld in the later case law of the “old" CT until 2016.

In another major judgment, rendered in 2010, the CT ruled on the constitutionality of the Lisbon Treaty. ${ }^{13}$ It developed the CT's position concerning Article 90 paragraph 1 of the Constitution in the context of the principles of sovereignty, supremacy of the Constitution, and constitutional identity. However, the specific aspects of the limits of the delegation of competences to the EU and the consequences of crossing those limits were not analyzed.

The next judgment of the CT of 2011 deserves closer inspection. ${ }^{14}$ In this ruling, the CT directly reviewed the conformity of EU secondary legislation with the Constitution for the first and the last time to date. The proceedings in this case were initiated as a result of a constitutional complaint from a Polish citizen who asserted that the provisions of Council Regulation (EC) No 44/2001 of 22.12.2000 on jurisdiction and the recognition and enforcement of judgments in civil and commercial matters, known as Brussels I, are incompatible with Article 45 of the Constitution granting individuals the right to court, and Article 32 which guarantees equality before the law. The complainant alleged that her subjective rights were infringed because she was excluded from proceedings before the Polish court of first instance, in a case regarding the enforceability of a foreign judgment. Having examined the case, the CT ruled that the contested provisions of the Council Regulation were consistent with the Constitution.

The judgment aroused controversy amongst lawyers. The subject of criticism was the submission of an act of EU law to be reviewed for its constitutionality. The Constitutional Tribunal

\footnotetext{
${ }^{13}$ Polish Constitutional Tribunal, Judgment of Nov. 24, 2010, Ref. No. K 32/09.

${ }^{14}$ Polish Constitutional Tribunal, Judgment of Nov. 16, 2011, Ref. No. SK 45/09.
} 
justified the admissibility of the control by the specificity of the review following a particular procedure of individual constitutional complaint. Pursuant to Article 79 paragraph 1 of the Constitution, a constitutional complaint may be submitted to the Tribunal by everybody to check "the conformity to the Constitution of a statute or another normative act", upon which basis a court or a public administration authority has made a final decision on a complainant's freedoms or rights or on his/her obligations specified in the Constitution. ${ }^{15}$

Having analyzed the characteristics of the EU regulations pursuant to Article 288 of the TFEU, the CT concluded that these very acts of EU secondary legislation may be a direct source of individual freedoms or rights and hence they bear the features of 'another normative act' within the meaning of Article 79 paragraph 1 of the Constitution. The point was the allegation that the norms of EU regulations infringe the constitutional rights and freedoms of the individual.

The CT emphasized that the Republic of Poland accepted the division of competences with regard to the review of legal acts. That division results in the jurisdiction of the Court of Justice to provide the final interpretation of EU law as well as to have an exclusive power to determine the conformity of the EU secondary legislation with the Treaties. In such a context, the CT referred to the extraordinary and subsidiary character of the jurisdiction of the CT to examine the conformity of EU law with the Constitution. Undoubtedly, a ruling declaring the non-conformity should have the character of ultima ratio and occur only when all other ways of resolving a conflict between Polish norms and the norms of the EU legal order have failed. The CT admitted that such a consequence of the CJ ruling would be difficult to reconcile with the obligations of a Member State and the principle of sincere cooperation (Article 4 paragraph 3 of the TEU). The said situation could even lead to an action brought against Poland before the CJEU for infringement of obligations under the Treaties (Articles 258-260 of the TFEU). Therefore, before adjudicating on the non-conformity of an act of EU secondary legislation with the Constitution, the CT should ascertain the content of the norms of EU secondary legislation which are subject to review. This may be achieved by referring questions to the CJEU for a preliminary ruling, pursuant to Article 267 of the TFEU.

The CT noticed similarities in this point to the approach taken by the Bundesverfassungsgericht (BVerfG) in the order of 2010 in the Honeywell case. ${ }^{16}$ However, there was a difference; namely, in the latter case the subject of the review was not an act of EU secondary legislation, but a judgment of the CJEU, and the allegation of non-conformity with the German Grundgesetz did not concern fundamental rights, but the issue of going beyond the scope of the competences conferred upon the EU (ultra vires action). The CT noticed, however, similarities between the case it examined and other judgments of the BVerfG, namely the order of 1986 in the Solange II case ${ }^{17}$ and the order of 2000 in the Banana Market case. ${ }^{18}$

Concluding its deliberations, the CT defined the approach to similar issues in the future. Namely, in the case of filing a constitutional complaint which challenges the conformity of EU regulations with the Constitution, the complainant should be required to make probable that the challenged act of EU secondary legislation causes a considerable decline in the standard of protection of rights and freedoms, in comparison with the standard of protection guaranteed by the Constitution.

To summarize, several characteristics of the CT approach can be identified. Firstly, it stresses the supremacy of the Polish Constitution also in time of EU membership. Secondly, much attention is paid to the interpretation of the notion of delegation to an international organization of

\footnotetext{
${ }^{15} \mathrm{I}$ am probably not fully objective having been the judge rapporteur in this case in the CT.

${ }^{16}$ Bundesverfassungsgericht [BVerfG] [Federal Constitutional Court] July 6, 2010, 126 ENTSCHEIDUNGEN DES BUNDESVERFASSUNGSGERICHTS [BVERFGE] 286.

${ }^{17}$ Bundesverfassungsgericht [BVerfG] [Federal Constitutional Court] Oct. 22, 1986, 73 ENTSCHEIDUNGEN DES BuNDESVERFASSUNGSGERICHTS [BVerfGE] 339 [hereinafter Solange II].

${ }^{18}$ Bundesverfassungsgericht [BVerfG] [Federal Constitutional Court], Case No. 2 BvR 1/97 (June 7, 2000), http://www. bverfg.de/e/ls20000607_2bvl000197en.html.
} 
"the competences of organs of the state authority in certain matters." Thirdly, it expresses loyalty and recognizes the role of the CJEU as the final adjudicating authority on the interpretation and validity of EU law. Fourthly, it deems the principles of conferral of the competences and primacy of EU law not to be unlimited. In one of its judgments, the CT mentioned the concept of ultra vires acts, although it did not refer to it in the ratio of its decision. It allowed however for the constitutionality of EU regulations to be examined when considering constitutional complaints. It considered this to be a very exceptional solution, subsidiary to the competence of the CJEU and admissible upon the fulfilment of strict requirements. In the period of almost 10 years since the judgment, in which such a procedure was applied, there was no further attempt to undermine the constitutionality of acts of EU law on the grounds of lowering the level of protection of fundamental rights.

\section{Breaching the Rule of Law in Poland}

The presidential and parliamentary elections in Poland in 2015 marked the beginning of a process of violating the Constitution as well as destroying the foundations of democracy and the rule of law by the legislature and executive. ${ }^{19}$ It covered various areas of political and social life. Below, destructive changes in one of these important areas will be synthetically presented: in the administration of justice.

The first to lose its independence was the Constitutional Tribunal (CT). This allowed the parliamentary majority to pass statutes without fear of being subjected to effective scrutiny of their constitutionality. In 2016, the Prosecutor's Office was fully subordinated to the Minister of Justice. Between 2017 and 2020, a number of statutes were issued to limit the independence of the Supreme Court (SC) and ordinary courts. Two new chambers were created in the SC, consisting of judges appointed in a procedure that ensures greater influence by politicians.

In 2017, a statute was passed to change the composition of the National Council of the Judiciary (NCJ). ${ }^{20}$ It is a constitutional body of great importance, whose main task is to make proposals to the President concerning candidates for judicial posts. The NCJ consists in its majority of judges. However, the way of appointing judges - members of the NCJ-was changed. While they were earlier elected by the General Assemblies of judges, according to the new law they are appointed by the Sejm (Parliament). The Act on the NCJ in its current form is considered unconstitutional by most legal circles and the legitimacy of judges appointed on the motion of the new Council is questioned.

The "reforms" carried out in the judiciary consisted mainly of staff exchanges. This became most apparent in the case of the SC judges. The new law lowered the judges' retirement age, which was expected to result in in the termination of the holding of office by more than one third of judges. In ordinary courts there was an exchange of presidents and vice-presidents by the Minister of Justice. In addition, the replacements of judges were the result of a new way of appointing and promoting them on the motion of the politicized NCJ.

The Polish authorities argued that the statutory changes to the administration of justice are compatible with the Constitution. This claim cannot be reliably verified in the light of the CT's subordination to political influence.

\footnotetext{
${ }^{19}$ See, e.g., W. Sadurski, Poland's Constitutional Breakdown (2019); M. Matczak, 10 Facts on Poland for the Consideration of the European Court of Justice, VerfassungSBlog (May 13, 2018), https://verfassungsblog.de/10-facts-onpoland-for-the-consideration-of-the-european-court-of-justice/; L. Pech \& P. Wachowiec, 1460 Days Later: Rule of Law in Poland R.I.P. (Part I), Verfassungsblog (Jan. 13, 2020), https://verfassungsblog.de/1460-days-later-rule-of-law-inpoland-r-i-p-part-i/; L. Pech \& P. Wachowiec, 1460 Days Later: Rule of Law in Poland R.I.P. (Part II), VERFASSUNGSBLOG (Jan. 15, 2020), https://verfassungsblog.de/1460-days-later-rule-of-law-in-poland-r-i-p-part-ii/.

${ }^{20}$ M. Matczak, The Rule of Law in Poland: A Sorry Spectacle, Verfassungsblog (Mar. 3, 2018), https://verfassungsblog.de/ the-rule-of-law-in-poland-a-sorry-spectacle/; Sadurski, supra note 19, at 99.
} 


\section{E. Reaction of EU Institutions to Violations of the Rule of Law in Poland}

The amendments to the statutes and the manner of their application, as presented, triggered a reaction from EU institutions concerned about Poland's violation of the rule of law, especially in the field of the judiciary. In 2016-2017, the Commission launched for Poland a new EU rule of law framework ${ }^{21}$ which failed, though. Therefore, in December 2017 the Commission decided to make a reasoned proposal to the Council to initiate proceedings against Poland under Article 7 TEU. The proceedings have been ongoing for more than two years, but there is no sign of the willingness of Member States to conclude them.

In this state of affairs, the CJEU became the leading institution, alongside the Commission, in the efforts to restore the rule of law in the troublesome Member State. This was undoubtedly due to the new line of jurisprudence launched in early 2018 by the landmark judgment on Portuguese judges. ${ }^{22}$ Since 2018, the Commission has filed complaints against Poland under Article 258 TFEU. To date, the CJEU has given two judgments following this procedure: In June 2019, it ruled on the incompatibility of the provisions lowering the retirement age for judges of the SC with EU law. ${ }^{23}$ In November 2019, it ruled that the legislation introducing a different retirement age for women and men in the positions of judges of ordinary courts is incompatible with EU law. ${ }^{24}$

Currently, proceedings are pending before the CJEU in the third case filed by the Commission. ${ }^{25}$ It concerns the model of disciplinary responsibility for judges which undermines judicial independence. In April 2020, the CJEU issued an order in which prescribed interim measures. They consisted in temporary suspension of judicial activities of the Disciplinary Chamber of the SC until the final judgment is delivered. ${ }^{26}$

In April 2020, the Commission addressed to Poland a letter of formal notice in the fourth case. The Commission requests Poland to put an end to the violation of EU law by the provisions of so-called "muzzle law" on the judiciary issued in early $2020 .{ }^{27}$ The statute provides, inter alia, for disciplinary proceedings against judges for applying EU law and judgments of the CJEU and for making preliminary references.

In addition, there are several proceedings under way following questions referred by Polish courts for preliminary rulings. ${ }^{28}$ These concern various aspects of the legal position of judges in the context of the requirements of their independence under EU law, as well as the status of persons appointed to judicial posts as a result of procedures which raise doubts as to their fairness.

\footnotetext{
${ }^{21}$ Communication from the Commission to the European Parliament and the Council on a New EU Framework to Strengthen the Rule of Law, COM (2014) 158 final, https://ec.europa.eu/transparency/regdoc/rep/1/2014/EN/1-2014-158-EN-F1-1.Pdf.

${ }^{22}$ ECJ, Case C-64/16, Associação Sindical dos Juízes Portugueses, ECLI:EU:C:2018:117 (Feb. 27, 2018), https://eur-lex. europa.eu/legal-content/EN/TXT/PDF/?uri=CELEX:62016CJ0064.

${ }^{23}$ ECJ, Case C-619/18, Eur. Comm. v. Republic of Poland, ECLI:EU:C:2019:531 (June 24, 2019), http://curia.europa.eu/ juris/liste.jsf?num $=\mathrm{C}-619 / 18$.

${ }^{24}$ ECJ, Case C-192/18, European Commission v. Republic of Poland, ECLI:EU:C:2019:924 (Nov. 5, 2019), http://curia. europa.eu/juris/liste.jsf?num $=\mathrm{C}-192 / 18$.

${ }^{25}$ ECJ, Pending Case C-791/19 (Oct. 25, 2019).

${ }^{26}$ Ordonnance de la Cour, Case C-791/19 R (Apr. 8, 2020). Translation into English is not available.

${ }^{27}$ See L. Pech, W. Sadurski, K.L. Scheppele, Open Letter to the President of the European Commission regarding Poland's "Muzzle Law", Verfassungsblog (Mar. 9, 2020), https://verfassungsblog.de/open-letter-to-the-president-of-the-europeancommission-regarding-polands-muzzle-law/.

${ }^{28}$ See ECJ, Pending Case C-824/18, A.B.; ECJ, Pending Case C-487/19, W. Ż.; ECJ, Pending Case C-508/19, Prokurator Generalny; ECJ, Pending Case C- 748/19, Prokuratura Rejonowa w Mińsku Mazowieckim; ECJ, Pending Case C-749/19, Prokuratura Rejonowa Warszawa-Żoliborz w Warszawie; ECJ, Pending Case C-750/19, Prokuratura Rejonowa Warszawa -Wola w Warszawie; ECJ, Pending Case C-751/19, Prokuratura Rejonowa w Pruszkowie; ECJ, Pending Case C-752/19, Prokuratura Rejonowa Warszawa-Ursynów w Warszawie; ECJ, Pending Case C-753/ 19, Prokuratura Rejonowa Warszawa-Wola w Warszawie; ECJ, Pending Case C-754/19, Prokuratura Rejonowa Warszawa-Wola w Warszawie; ECJ, Pending Case C-55/20, Ministerstwo Sprawiedliwości.
} 
The recent judgment of the CJEU of November 2019 deserves special attention. Its contents and far-reaching consequences will be presented below. ${ }^{29}$

\section{F. Reactions of the Polish Authorities to the Activities of EU Institutions}

The answer of the Polish authorities to the interest of the EU institutions in the situation in Poland has been constant over the last five years. Politicians have emphasized that all undertakings are in accordance with the Constitution and serve to improve the functioning of the judiciary. In addition, which is of particular importance here, whenever EU institutions requested information on changes in the field of the judiciary in Poland, and then took steps to stop violations of the rule of law, the Polish authorities consistently responded by raising the argument that the organization and functioning of justice is an internal matter for a Member State. Claims were made that this area falls outside the competence of the Union because the requisite competences were not conferred by the Member States in the Treaties. Interventions by the Union institutions in defense of the independence of the courts and judges were and are therefore considered by the Polish authorities to be devoid of Treaty grounds and therefore inadmissible. Added to this was a belief that the transformations taking place in the Polish judiciary are consistent with EU values and similar solutions found in other countries. The argument of taking action by EU institutions outside their competence was raised by Poland on various occasions: in responses to letters of formal notice, responses to reasoned opinions and to actions in individual cases under Article 258 TFEU, as well as in government positions in preliminary ruling proceedings.

In support of the thesis of a purely internal nature of the States' competence in the field of the judicial system, the Polish authorities refer to the case law of the CJEU. However, they do so in a selective and thus distorted manner. A characteristic example is the frequent quotation by politicians in the official documents and in the media of the phrase that "the organization of justice falls within the competence of the Member States" omitting the full wording of the Court's statement: "Furthermore, although, as the Republic of Poland and Hungary point out, the organization of justice in the Member States falls within the competence of those Member States, the fact remains that, when exercising that competence, the Member States are required to comply with their obligations deriving from EU law." 30

Even a rough analysis of EU law leads to the conclusion that the view expressed by the Polish authorities that the judiciary system and legal proceedings remain within the exclusive competence of Member States is indefensible. The statements of Polish politicians do not take account of the new line of jurisprudence of the CJEU initiated by the aforementioned judgment on Portuguese judges. This position deserves to be commented on and evaluated.

It is obvious that issues such as the structure of the judiciary or the court's procedure itself remain within the competence of the Member States. However, EU law includes those aspects of the organization and functioning of the judiciary that are related to the role of national courts as European courts applying Union law. This role follows from Article 19 paragraph 1 third sentence TEU, Article 267 TFEU, Articles 81-82 TFUE and Article 47 ChFR. National courts are therefore required to comply with the standards of EU law. One of the most important requirements is the independence and impartiality of courts and judges as part of the rule of law being one of the values of the Union (Article 2 TEU). Compliance with this requirement is subject to control by the EU institutions. ${ }^{31}$

\footnotetext{
${ }^{29}$ See infra note 32.

${ }^{30}$ See European Commission v. Republic of Poland, Case C-619/18 at 52. Identical or similar statements can be found in other rulings.

${ }^{31}$ See e.g. ECJ, Case C-216/18 PPU, LM (Celmer), ECLI:EU:C:2018:586 (July 25, 2018), http://curia.europa.eu/juris/liste.jsf? num $=C-216 / 18$.
} 


\section{G. A Recent Bone of Contention in the Relations between Poland and the European Union}

Note has already been made above to the judgment of the CJEU of November $2019 .{ }^{32}$ It was delivered in response to several preliminary references from the SC. The essential legal problem in this case was the assessment under EU law of the procedures for appointing judges in the context of ensuring their independence. The CJEU formulated in the judgment under consideration detailed conditions to be met under EU law for the recently established Disciplinary Chamber of the SC in Poland to be regarded as a "court" for the purpose of EU law and for the NCJ involved in the procedure for appointing judges to be separated from the legislative and executive powers.

Following the guidelines contained in this judgment of the CJEU, the Polish SC issued several judgments in its execution in which it concluded that the Disciplinary Chamber of the SC does not meet the requirements for a "court" under EU and Polish law, and that the NCJ, in the current legal situation, does not warrant a fair procedure for the presentation of candidates for judges to the President. ${ }^{33}$

As many Polish courts still had doubts about the consequences of the CJEU judgment, the SC adopted a resolution in January 2020 in order to unify the case-law. ${ }^{34}$ Judges of the SC from three chambers (out of five), appointed prior to the aforementioned 2017 statutory amendments concerning the NCJ, participated in issuing this resolution. The SC considered the impact on the exercise of individuals' right to judicial protection under Article 45 of the Constitution, Article 6 of the ECHR, and Article 47 of the CFR in the light of the fact that the adjudicating courts are sometimes composed of persons appointed by the President on the motion of the NCJ, following the new procedure. The SC deems the new procedure unconstitutional due to the composition of the NCJ, its politicization and lack of independence. The flawed procedure has the effect of undermining the standard of independence and impartiality of the judges appointed thereunder. In conclusion, the SC's resolution stated that judges of the SC appointed under the new procedure should be removed from adjudication. In turn, judges of ordinary courts in this category should refrain from adjudicating until it is established whether the flawed process of their appointment led to a breach of the standard of independence and impartiality in individual circumstances.

The SC's resolution of January 2020 encountered fierce criticism from politicians on the government's side. The aforementioned "muzzle law" of January 2020 was issued in response, providing, among other things, for disciplinary responsibility for judges challenging the President's appointment under the new procedure.

In addition, the $\mathrm{SC}$ resolution in question was challenged in the $\mathrm{CT}$. The politically dependent Polish constitutional court allowed this resolution to be reviewed even though it did not fall within its jurisdiction and ruled that the SC's resolution was unconstitutional. ${ }^{35}$

In other parallel proceedings, the CT decided on a dispute artificially created by the Speaker of the Sejm over competence ${ }^{36}$ between the SC and the Sejm and the President as a result of the aforementioned resolution of the SC. ${ }^{37}$ This ruling evaluated not only the CT the SC's resolution

\footnotetext{
${ }^{32}$ ECJ, Joined Cases C-585, 624, \& 625/18, A.K. v. Krajowa Rada Sądownictwa, ECLI:EU:C:2019:982 (Nov. 19, 2019).

${ }^{33}$ Most significant was Supreme Court of Poland, Case No. III PO 7/18, Judgement of Dec. 5, 2019.

${ }^{34}$ Resolution of the Panels of the Combined Chambers: Civil, Criminal as well as Labor and Social Security of the Supreme Court of January 23, 2020, SĄD NAJWYŻszy (Jan. 23, 2020), http://www.sn.pl/aktualnosci/SitePages/Wydarzenia.aspx? ItemSID=598-0dc69815-3ade-42fa-bbb8-549c3c6969c5\&ListName $=$ Wydarzenia\&rok $=2020$.

${ }^{35}$ Polish Constitutional Tribunal, Judgment of Apr. 20, 2020, Ref. No. U 2/20 https://trybunal.gov.pl/en/hearings/ judgments/art/11040-uchwala-skladu-polaczonych-izb-cywilnej-karnej-oraz-pracy-i-ubezpieczen-spolecznych-sadunajwyzszego-z-dnia-23-stycznia-2020-r-sygn-akt-bsa-i-4110-120.

${ }^{36}$ This is a special type of procedure before the CT (Article 189 of the Constitution).

${ }^{37}$ Polish Constitutional Tribunal, Judgement of Apr. 21, 2020, Ref. No. Kpt 1/20, https://trybunal.gov.pl/en/hearings/ postanowienia/art/11047-spor-kompetencyjny-miedzy-sejmem-rp-a-sadem-najwyzszym-oraz-miedzy-prezydentem-rp-asadem-najwyzszym. Five judges made dissenting opinions which concerned disputable aspects of Polish law.
} 
but also the CJEU's judgment of November 2019 which provided an impulse for passing that resolution. The position of the CT in this case is of particular relevance in the context of these considerations. The main statements regarding EU aspects of the ruling may be summarized as follows: ${ }^{38}$ Both the resolution of the SC of January 2020 and the previous judgment of the CJEU of November 2019 are contrary to the Polish Constitution. In the light of the Treaties, the CJEU has no competence in the judicial system of the Member States. The CJEU judgment could not be treated by the SC as a basis for deciding on matters falling within the exclusive constitutional competence of Polish state authorities, that is the Sejm and the President of Poland. The SC's conviction of the binding character of CJEU judgments in cases which have not been conferred to the EU by the Treaties is incorrect. Furthermore, judgments of the CJEU are not amongst the sources of EU law listed in Article 288 TFEU.

Commenting on this judgment, note is to be made of its most striking feature that EU law was understood by the CT in a highly simplified manner. No attempt was made to interpret the Treaties in any way, no reference was made to case-law or the legal literature. The 'judiciary', as the field of an exclusive competence of the Member States, was treated as a whole, without any distinctions made within it or without linking it to the entirety of EU law.

The level of the ruling discussed here demonstrates a considerable fall of the CT compared with the judgments covered above from before 2016. Ignoring the attainments to date in the area of interpretation of the Constitution in the context of Poland's membership in the EU, the constitutional court found the actions of EU institutions in the matters of the national judiciary to have been taken on ultra vires basis.

The position of the Polish CT is thus radical, more so than the BVerfG judgment in the PSPP case, and of potentially higher relevance for EU law. Indeed, the subject matter of the Polish ruling, that is judicial protection, is central for EU law. Significantly, however, the Polish judgment discussed here has not attracted attention in EU institutions, not even in Poland or amongst commentators. This is probably related to the fact, as already mentioned, that the Polish CT has lost its prestige in recent years. In the ruling in question, the CT decided in line with the expectations of the Polish authorities. This is, after all, a feature that has characterized the entire jurisprudence of the CT since 2017 in cases with sensitive political elements, which meets the wishes of the ones currently in power. ${ }^{39}$ In the press interview mentioned above, A. Voßkuhle briefly answered the question whether a court like the Constitutional Court in Poland is still a partner for BVerfG: "No. It is no longer a serious court, it is a puppet." Regrettably, this opinion is to be supported. ${ }^{40}$

However, the importance of the ruling of the CT presented above cannot be underestimated. Politicians needed it compellingly to strengthen, with the formal authority of the national constitutional court, the position already presented by the Polish government. They will be able at last to invoke this judgment both in Poland and externally, especially in contacts with EU institutions. To date, judgments of the CJEU in cases concerning the judiciary have generally been respected, even if with a delay and not fully, despite their criticism by the Polish authorities and the questioning of the competence to issue them. The last ruling of the CT can, however, be used to prove the superiority of the jurisprudence of national constitutional courts over that of the CJEU. Currently, after this ruling, the Polish parliament and government will be able to refuse to enforce acts of EU institutions or judgments of the CJEU on the grounds that they have been rendered outside the Treaty mandates, as confirmed by the national constitutional court having the last say.

\footnotetext{
${ }^{38}$ The discussion of this ruling is based on a press release. Its full statement of reasons was not yet published when this Article was written, two months after the ruling had been issued.

${ }^{39}$ See documented analysis in M. PyZiak-Szafnicka, Trybuną Konstytucyjny $\otimes$ Rebours 25 (2020). The author is a former judge of the CT.

${ }^{40}$ This statement was commented upon by Ms J. Przyłębska, the current President of the Polish Constitutional Tribunal: "The scandalous statement by the President of the German Constitutional Court does not fit into any canon of fair public debate. I am embarrassed that a person in such an important position is speaking in such a way.” A few days earlier, Ms Przyłębska had praised the PSPP judgment.
} 


\section{$\mathrm{H}$. What the BVerfG Judgment in the PSPP Case May be Useful For}

The potential impact of the German BVerfG judgment, which was based on the concept of ultra vires acts, is evident in the current situation of Poland.

On the same day on which the judgment in the PSPP case was given, two deputy ministers of justice spoke about it at a press conference. ${ }^{41}$ One may have doubts, however, whether they had time at all to read the judgment or even its summary. These politicians stated that the German ruling has a "colossal relevance" for the dispute between Poland and the Commission about the judiciary. In their opinion, the German judgment confirms the position of the Polish government which accuses EU institutions of exceeding the powers conferred upon them. This is the situation in which the constitutional courts of the Member States step in. In this context, politicians praised the ruling of the Polish CT issued two weeks earlier. In their view, the BVerfG judgment is a manifestation of the defense of German sovereignty, whereas the analogous position of Poland was criticized by representatives of the Commission. "I wonder if the Commission will comment on the judgment of the German constitutional court in the same way", added sarcastically one of the deputy ministers, not expecting that an action against Germany under Article 258 TFEU would be considered soon afterwards.

The Polish Prime Minister Mateusz Morawiecki spoke about the ruling of the BVerfG with Frankfurter Allgemeine Zeitung. ${ }^{42}$ He termed it "one of the most important judgments in the history of the EU / . . / This is perhaps the first time that this has been said with such clarity: The Treaties are created by the Member States and they determine where the limits of competence lie for the EU institutions." Similar judgments have been handed down by courts in other European states, including the Polish CT. The CJEU has "very extensive powers", but only "in the field arising out of decisions taken by the States." Attempts to extend this area were "arbitrary and dangerous for the rule of law." In his opinion, every mature democracy needs a system of separation and balance of powers. "In the absence of such a system, all violence, including that of the judiciary, becomes an arbitrary, unlimited, undemocratic power." Morawiecki expressed his hope at the end that thanks to the Karlsruhe ruling "a real debate will begin in the EU on how to ensure this balance and a mechanism for its control at the Union level."

As it seems, no other European politician of this rank has expressed such a clear approval of the BVerfG judgment or has placed great hopes in it for the future. Nor has anyone taken it as a starting point for a general debate on the change in the relations between the $\mathrm{EU}$ and the Member States, or between the CJEU and the national constitutional courts. It is hard to imagine that another prime minister of a Member State (perhaps with the exception of Hungary) would speak in such a simplified and generalized way about the competences of the CJEU and their "arbitrary and dangerous" extension. The comments on the "separation and balance of powers" are ambiguous: it is not clear whether they refer to the system within particular states or to the relations between the Member States and the Union. The term "primacy of EU law" is not used in this statement at all.

It can also be added that Ms. Julia Przyłębska, President of the CT since the end of 2016, praised BVerfG for confirming that national constitutional courts are the courts having the last word, as the Polish CT found in April 2020. ${ }^{43}$

\footnotetext{
${ }^{41}$ See Polish Ministry of Justice, The Judgement of the German Constitutional Court Confirms Poland's Position in the Dispute with the European Commission, Gov.PL (May 12, 2020), https://www.gov.pl/web/justice/the-judgement-of-thegerman-constitutional-court-confirms-polands-position-in-the-dispute-with-the-european-commission.

${ }^{42}$ See Thomas Gutschker, Konrad Schuller, \& Gerhard Gnauck, EU droht Deutschland mit Verfahren, FRANKFURTER Allgemeine Zeitung (May 9, 2020), https://www.faz.net/aktuell/politik/eu-droht-deutschland-mit-vertragsverletzungsver fahren-16762097.html.

${ }^{43}$ See Prezes Przyłębska: „Krajowe TK sq sq̨dami ostatniego słowa. Potwierdził to Trybunał Niemiec”, TVP INFO (May 5 , 2020), https://www.tvp.info/47893367/prezes-przylebska-krajowe-tk-sa-sadami-ostatniego-slowa-potwierdzil-to-trybunalniemiec.
} 
Regardless of how the correctness of the BVerfG judgment in the PSPP case is assessed, its use as a serious argument in the conflict between Poland and EU institutions is flawed. The common feature of the BVerfG judgment in the PSPP case and the last ruling of the Polish CT is the lack of approval for making the CJEU judgments binding in each case. However, important differences prevail. The German judgment contains a statement of reasons, which should be underlined here, irrespective of whether these reasons are considered convincing. ${ }^{44}$ The Polish judgment, on the other hand, does not contain any substantive explanation for excluding the application of EU law and the case-law of the CJEU in the whole area of the judiciary of Poland. The BVerfG does not challenge the competence of the CJEU to rule on the interpretation and validity of EU law. Reference to the ultra vires concept is reserved to exceptional situations even though determined otherwise than in earlier case-law. ${ }^{45}$ The Polish CT in the last judgment discussed here, in contrast to previous case-law, seems, on the other hand, to treat national constitutional courts as having the general power to decide when the case-law of the CJEU can be ignored.

It is to be noted at the same time that the reference in Poland to the BVerfG's jurisprudence is incomplete. Politicians might not know (and their advisors do not provide the information) that next to judgments which may be deemed to demonstrate some distance to the EU, the German constitutional court issues also landmark judgments which are fully based on the Union concept of fundamental rights and confirm the primacy of EU law. ${ }^{46}$ Such rulings are not taken note of in the Member States which infringe the rule of law even though they could be a good point of reference for them. ${ }^{47}$

The selective reference by the Polish authorities to the BVerfG jurisprudence in order to strengthen its reluctant approach to EU law does not stand up in legal terms. Poland's position in relations with EU institutions cannot be expected to improve. The experience of recent years allows a prediction, however, that the German example is likely to be used more extensively in the future for political and propaganda reasons.

\footnotetext{
${ }^{44}$ See Judgement of May 5, 2020 at para. 112.

${ }^{45}$ See analysis of earlier case-law of the BVerfG on ultra vires, D. Grimm, M. Wendel, \& T. Reinbacher, European Constitutionalism and the German Basic Law, in NATIONAL Constitutions In European and Global Governance: Democracy, Rights, the Rule of Law 423 (A. Albi \& S. Bardutzky eds., 2019). See also in the wider union context, M. Kawczyńska, The Court of Justice of the European Union as a Law-Maker: Enhancing Integration or Acting ultra vires?, in Judicial LaW-Making in European Constitutional Courts 207-210, 219-220 (M. Florczak-Wątor ed., 2020).

${ }^{46} \mathrm{See}$ Bundesverfassungsgericht [BVerfG] [Federal Constitutional Court], Case No. 1 BvR 16/13 (Nov 6, 2019), http://www. bverfg.de/e/rs20191106_1bvr001613.html [Right to be Forgotten I]; Bundesverfassungsgericht [BVerfG] [Federal Constitutional Court], Case No. 1 BvR 276/17 (Nov 6, 2019) http://www.bverfg.de/e/rs20191106_1bvr027617.html [Right to be Forgotten II].

${ }^{47}$ See Matthias Goldmann, As Darkness Deepens: The Right to be Forgotten in the Context of Authoritarian Constitutionalism, 21 GERMAN L.J.. 45 (2020).
}

Cite this article: Biernat S (2020). How Far Is It from Warsaw to Luxembourg and Karlsruhe: The Impact of the PSPP Judgment on Poland. German Law Journal 21, 1104-1115. https://doi.org/10.1017/glj.2020.53 